\title{
Omhändertagande med barnets perspektiv
}

\author{
ANN-CHRISTIN CEDERBORG \& YVONNE KARLSSON
}

\author{
Förenta Nationernas barnkonvention har fätt en genom- \\ gripande betydelse för lagstiftarnas politiska ambitioner \\ inom svensk socialvård. Det innebär att barn har rätt \\ att få sitt perspektiv i fokus när socialtjänsten behandlar \\ ärenden som berör honom eller henne. Vid alla åtgärder \\ som rör barn som misstänks fara illa ska hans eller hennes \\ bästa komma i främsta rummet. Genom en studie i en \\ svensk medelstor kommun belyses hur det förhäller sig med \\ barnkonventionen i praktiken.
}

\begin{abstract}
Många studier om barn och deras delaktighet i socialtjänstens arbete med dem bygger framförallt på uppgifter från olika typer av skriftlig dokumentation (exempelvis Börjeson \&Håkansson, 1990; Claezon, 1987; Hagbard \& Esping, 1992; Hollander, 1985; 1998; Mattson, 1998; Reder \& Duncan,1999; Vinnerljung, 1989; 1996; Wåhlander, 1995). Studierna visar att akterna innehåller få uppgifter om barn och deras livssituationer. Relationerna med barnen i familjen beskrivs knapphändigt. Fokus tenderar i stället att

Docent Ann-Christin Cederborg är universitetslektor i psykologi och verksam vid Institutionen för Beteendevetenskap och tema Barn vid Linköpings universitet.

Doktorand Yvonne Karlsson är verksam vid Institutionen för Utbildningsvetenskap vid Linköpings Universitet.
\end{abstract}

hamna på vuxnas bekymmersamma sociala situation i samband med utredningar och åtgärder. Ofta framkommer det inte heller om barnet är delaktigt eller ens medvetet om den process som pågår om dess utsatthet. Likaså har Socialstyrelsen noterat att när socialnämnden ansökt vid länsrätten om att få omhänderta barn och ungdomar, på grund av brister i hemmiljön ( $\$ 2 L V U$ ), så får barnet inte det största utrymmet i socialnämndens skriftliga underlag utan beskrivningarna om barn kommer i huvudsak från andra professionella (Barnet i rättsprocessen, SOS-rapport 1995:21).

Det finns nationella och internationella studier där utsatta barns tankar, känslor och beskrivningar av sin verklighet som omhändertagna blir belysta både av socialsekrete-

Cederborg, A.-C. \& Karlsson, Y.: Omhändertagande med barnets perspektiv 
rare, barnen själva eller andra vuxna i deras närhet (exempelvis Andersson, 1991; 1995; 1998a; 1999; Butler \& Williamson, 1994; Cleaver, Unell \& Aldgate,1999; Farmer \& Owen, 1995; Hessle, 1998; Levin, 1998; Pringle \& Harder, 1999; Quinton, Rushton, Dance \& Mayes, 1998). Studierna har olika utgångspunkter men ovan nämnda studier visar också att barn som bedömts fara illa i sina hemmiljöer sällan är medaktörer i socialtjänstens aktiviteter som berör dem. Detta sker alltså trots att forskare lyft fram nödvändigheten av att respektera barnet som subjekt, medaktör och som viktig informationskälla när dess verklighet ska förstås (James \& Prout, 1990; Qvortrop m.fl., 1994). Problemet med att socialtjänsten inte i tillräcklig utsträckning synliggör barns perspektiv har också behandlats i Kommittédirektiven för översyn av lagen med särskilda bestämmelser om vård av unga (1999: 43). Vi vet alltså inte tillräckligt mycket om hur dessa barn uppfattar samhällsåtgärder som syftar till att deras bästa tillgodoses. „Om barnen själva kommer till tals kan kunskapen om vad barn behöver komma att ändras" (SOU 2000:77).

Barn som misstänks fara illa i sina hemmiljöer är mycket utsatta. Därför är det angeläget att förstå hur de uppfattat socialtjänstens bevakning av deras intressen. För att värna om deras åsikter är syftet med denna studie att få fram egen beskrivning av vad de varit med om. Barnet bör göras till medforskare i stället för undersökningsobjekt (Andenaes, 1991). Studien gör inte anspråk på att servera sanningen om vad som faktiskt hänt. Däremot avses att lyfta fram vad det enskilda barnet formulerar om sina upplevelser och erfarenheter.

\section{Studiens aktualitet}

Förenta Nationernas barnkonvention är uttryck för en internationell ambition att höja barns status i ärenden som rör dem. I artikel 3 sägs exempelvis att: »Vid alla åtgärder som rör barn, vare sig de vidtas av offentliga eller privata sociala välfärdsinstitutioner, domstolar, administrativa myndigheter eller lagstiftande organ, skall barnens bästa komma i främsta rummetu. Barn ska också ha rätt att uttrycka sin mening i alla frågor som rör dem. Något som är en tydlig markering av att det berörda barnet ska få uttala sig (artikel 12). Sverige ratificerade FN:s barnkonvention 1990 och därmed förväntas dess regleringar genomsyra alla beslut som rör barn.

Det synsätt som förmedlats via barnkonventionen har påverkat svensk sociallagstiftning vad gäller ambitionen att synliggöra och förstå barnens perspektiv i utredningsarbeteom deras utsatthet. Socialsekreterare ska exempelvis noga försöka ta reda på hur barn upplever sin situation och vilka följder ett visst beslut kan få (SOU 1997:116). När socialsekreterare utreder ett (SOL §50) ärende där det finns misstanke om att barn kan fara illa ska utredaren särskilt beakta vad som är att förstå som barnets bästa (SOL §1). Hänsyn ska tas till barnets vilja med beaktande av barnets ålder och mognad (SOL §9). Socialtjänsten ska dessutom skaffa sig en bild av det enskilda barnet och dess behov utan att det pressas på synpunkter. Det betyder också att dess inställning ska klargöras utan att sättas i en svår valsituation ( Socialstyrelsen, 2000). Barn över 15 år ska höras men även yngre barn, som skulle kunna ta ställning i sakfrågan, 
bör ha rätt att samtala med utredaren om han eller hon bedömts förstå vad som föranleder utredningen. Barnet kan alltså ha rätt till inflytande i samband med att deras hemsituation utreds. Socialsekreteraren som utreder eventuella missförhållanden bör därmed se sig själv som en viktig samtalspartner för barnet (Andersson, 1998).

När socialsekreterare utreder barns utsatthet gäller det att förstå hur ett beslut eller en åtgärd kan uppfattas utifrån barnets perspektiv (Andersson, 1995). Vad barnets perspektiv innebär är inte alldeles enkelt att konkret definiera. Det kan snarare beskrivas som mångtydigt och komplext. Såväl barns som vuxnas beskrivningar formas individuellt utifrån skilda förutsättningar, sammanhang och positioner (Rasmusson, 1994). Vuxna har exempelvis varit barn men har för övrigt helt unika erfarenheter av och kunskaper om vad detta innebär. En vuxens perspektiv på hur det är att vara barn behöver därmed inte vara det samma som barnets eget. Faktorer som ålder, kön och social klass inverkar också på barnets verklighetsbeskrivning. Begreppet barnperspektiv kan även utgå ifrån en respekt för barnets fulla människovärde och integritet och rätt att betraktas som expert på sin egen situation. Det kan dessutom beskrivas som det sätt barnet beskriver hur världen ser ut, vad det ser, hör, upplever och känner (Tiller, 1991). Vad som än menas finns ändå en huvudprincip, nämligen den att försöka förstå hur barn uppfattar och upplever sig själva och sin relation till andra. Kravet på ett barnperspektiv kan faktiskt tolkas så att socialtjänsten ska fokusera utredningen med utgångspunkt från barnets beskrivning av sin situa- tion, även om det är vuxna som till slut har att tolka och ta ansvar för vad som framstår som det rätta för barnet.

\section{Tillvägagångssätt}

\section{Urval}

I en medelstor svensk kommun med ca 150000 invånare tillfrågades den sociala myndigheten om att få belysa omhändertagna barns perspektiv på socialtjänstens bemötande. Upplägget av studien skedde i nära samarbete med en ansvarig tjänsteman. I urvalet ingick alla barn som omhändertagits enligt LVU§2 och i vissa fall $\mathrm{i}$ kombination med $\S 3$ under åren 1994-1998. Samtliga hade sålunda bedömts ha bristande hemförhållanden och vara i behov av samhällsvård i någon form under den ovan nämnda perioden.

Socialtjänsten gjorde den första bedömningen av vilka barn över 4 år som var lämpliga att tillfråga om deltagande. Inom ramen för projektet var det 40 barn i åldrarna 5-19 år som bedömdes kunna delta i studien. Den lägre åldersgränsen sattes utifrån att barn då kan ha en utvecklingspsykologisk kompetens att berätta om sina erfarenheter tillsammans med en kompetent intervjuare (Lamb, 1994). Medgivande om att delta lämnades av barnet självt men också av dess föräldrar genom en anställd inom socialtjänsten. Först tillfrågade denna person de barn som var aktuella 1998, därefter de följande årskullarna tills projektet hittat 20 barn som ville och kunde vara med. Om någon tillfrågad ansåg att barnet skulle kunna fara illa av att delta var rekommendationen att barnet inte skulle ingå i studien. Ingen skulle över-

Cederborg, A.-C. \& Karlsson, Y.: Omhändertagande med barnets perspektiv 
talas till att delta. Sedan tillstånd om deltagande hade inhämtats via socialtjänsten bokade en av forskarna tid för barnintervjun.

Av 40 möjliga barn att tillfråga var det 20 som av flera skäl inte kunde inkluderas, av dem var det $i$ åtta fall barnen som avböjde deltagande och i 12 fall föräldrarna. Sju flickor och 13 pojkar ingår slutligen i studien. När dessa intervjuades var fem 5-7 år, fyra 8-10 år, sex 12-15 år och fem var 16-19 år. Av de 20 barnen omhändertogs fyra 1998, lika många 1997, 1996 sju, 1995 tre och 1994 två.

Studien har granskats och godkänts av forskningsetiska kommittén vid Linköpings Universitet.

\section{Intervjun}

För att minska risken för påverkan på svaren inhämtades ingen annan förhandsinformation än barnets namn och adress före intervjun. Av samma skäl var det en och samma person som ställde frågorna. Intervjun utgick ifrån en halvstrukturerad intervjuguide, indelad i följande tre huvudområden: Hur uppfattar det sin deltagarstatus i omhändertagandeprocessen? Hur har barnet uppfattat att dess perspektiv togs till vara under utredningsarbetet? Hur beskriver det sin situation som samhällsplacerat?

Intervjuaren strävade efter att inta ett okritiskt, empatiskt förhållningssätt samt att omsorgsfullt ställa inviterande frågor och därefter lyhört lyssna på det individuella barnets berättelse. Genom att, i så stor utsträckning som möjligt, ställa öppna inviterande frågor var ambitionen att få fram barnets egen berättelse av vad han eller hon varit med om. Det barnet berättade följdes sedan upp med mer fokuserade frågor. Om barnet uttalade värderingar av socialtjänstens agerande ombads det att ge konkreta exempel.

Även om intervjuaren hade ett öppet och inviterande förhållningssätt bör berättelserna förstås utifrån att de framkommit i samspel med intervjuaren. Det innebär att barnet kan ha påverkats till att berätta på ett visst sätt och att intervjuaren är delaktig i hur berättelsen växte fram (se exempelvis Holstein \& Gubrium, 1995; Hydén, 1997). Intervjuerna genomfördes under våren 1999 i ett enskilt ostört rum i barnets dåvarande hem. Intervjutiden varierade mellan 30-60 minuter, allt spelades in på ljudband och inga anteckningar gjordes under tiden.

\section{Bearbetnings- och analysprocess}

Samtliga intervjuer skrevs ut ord för ord och alla identifierbara fakta avkodades för att ingen medverkande eller omnämnd person skulle kunna identifieras. Det innebär att de personuppgifter som anges $i$ artikeln inte är i överensstämmelse med ursprungsfakta. Anonymiseringen påverkar inte de poänger som lyfts fram.

Berättelsernaharbearbetatsutifrån enkvalitativ ansats. Tolkningsverksamheten startade i samband med genomlyssnandet av intervjuerna och fortsatte genom de olika faserna i arbetet, vid transkriberingen, bearbetningen, analysen och skrivprocessen (Kvale, 1990). Innehållet i barnens berättelser har varit i fokus för analysprocessen. Det gällde att induktivt söka efter tematiskt 
innehåll i det unika barnets beskrivningar av sina upplevelser.

I analysprocessen ingick att söka likheter och olikheter i barnens tankar och funderingar omkring sina erfarenheter (se exempelvis Riessman, 1993; Holstein \& Gubrium, 1995; Hydén, 1997). Under bearbetningsprocessen framträdde alltmer tydliga mönster i barnens berättande. Dessa indelades i olika typer av över- och underkategorier. Det tematiska innehållet kom genomgående att handla om barnens beskrivningar av utsatthet både före, under och efter omhändertagandeprocessen.

\section{Barns utsatthet}

Barnen berättar om föräldrar, som av olika skäl, kan ha försummat deras behov. De bekräftar att de levt i sociala riskmiljöer när socialtjänstens startade sin utredning. Därmed legitimerar deras beskrivningar att $\S 50$ utredningar enligt Socialtjänstlagen påbörjades och LVU utredningar enligt §2 och $\S \S 2$ 2och 3 kom till stånd. Nedan följer ett sammandrag av vad barnen angav som orsak till socialtjänstens omhändertagande.

\begin{tabular}{|lc|}
\hline Tabell 2 & \\
Anledning till omhändertagande & \\
& \\
Orsak & Antal barn \\
Barnmisshandel & 4 \\
Förälder missbrukar & 5 \\
Psykisk sjuk förälder & 3 \\
Förälder "klarar inte av föräldraskap" & 3 \\
Eget beteende + "förälder orkar inte" & 2 \\
Eget beteende & 1 \\
Omedvetna om orsak & 2 \\
& \\
\hline
\end{tabular}

Det framkommer att 15 barn huvudsakligen ser föräldrarnas agerande som anledning till socialtjänstens ingripande. Men det är också ett par barn som säger sig vara omedvetna om orsakerna. Urvalet av barn grundade sig på socialtjänstens bedömningar om problematiska hemmiljöer. Ändå är det ett barn som anger sitt eget beteende som orsak. (Se tabell 2.)

När barnen beskriver sina erfarenheter av socialtjänstens bemötande blir det tydligt att de inte känt sig involverade i de åtgärder som syftade till att bevaka deras intressen. Huvuddelen av dem har inte uppfattat

\section{Tabell I \\ Berättelser om utsatthet Huvudkategori \\ Uteslutna som samtalspartners \\ Underkategori \\ Samtalas om under utredningsprocessen Oinformerade om socialtjänstens agerande Ej tillfrågade vid val av "vårdare" \\ Inte individuella samtalspartners under placeringstiden 13 \\ Obehagliga känsloupplevelser Övergivna vid placering till annat boende 14 Inte tagna på allvar $\quad 14$ \\ Saknar sin "biologiska" familj 16 \\ Känsla av främlingskap i familjehem 12 \\ Ensamhetskänslor under placeringstiden. $\quad 7$ \\ Bestraffad

Antal
14
18
17
13
14
14
16
12
7
6

Cederborg, A.-C. \& Karlsson, Y.: Omhändertagande med barnets perspektiv 
att deras perspektiv varit i fokus vare sig under utredning eller efter placering.

Följande teman med underkategorier ligger till grund för den kommande redogörelsen av vad barnen berättar om socialtjänstens aktiviteter. (Se tabell 1.)

Det är framförallt två huvudteman som barnen redogör för. Det ena är att de känner sig uteslutna som samtalspartners. Men de redogör också för obehagliga känsloupplevelser både före, under och efter att samhällsåtgärder satts in.

För att ge en bild av barnens beskrivningar följer här exempel från respektive tema.

\section{Uteslutna som samtalspartners}

\section{Samtalas om under utredningsprocessen}

Ett tema som återkom upprepade gånger var att 14 av barnen uppfattade att de uteslutits som aktiva samtalspartners under utredningsprocessen. Carl omhändertogs när han var 11 år. Han levde då med sina syskon och sin biologiska mamma. Så här berättar han om ett tillfälle när socialsekreteraren besökte hemmet i samband med LVU utredningen om hans och syskonens problematiska hemsituation. I= Intervjuaren och C= Carl.

\section{Exempel 1 Carl 12 år}

I: De kom alltså dit och besökte?

C: De kom väl en 3-4 gånger ungefär.

I: Tre - fyra gånger?

C: Ja.

I: På hur lång tid?
C: Inte vet jag.

I: Var det några år eller var det ett år.

C: Något år eller halvår.

I: Hm. Vem pratade de med?

C: Vad sade du?

I: Vem pratade de med när de kom?

C: Med mamma.

I: Men din mamma? Var du med då

så att du hörde?

C: Nej.

I: Var fick du vara då?

C: Jag var ute. Mina små syskon var också ute. Vi lekte då.

I: De pratade inte med er? Hur

ni hade det?

C: Nej, inte vad jag kommer ihåg.

Carl säger att han inte kommer ihåg att han fick delta i samtalen mellan mamman och socialsekreteraren om hans och syskonens framtid trots att denna utredningsprocess kom att påverka hans framtid flera år framöver.

\section{Oinformerade om socialtjänstens agerande}

Det är 18 berättelser om att barnen är oinformerade om socialtjänstens planerade åtgärder för dem. Totalt var det 14 barn som berättade om detta och 10 berättelser handlade om att barnen inte informerats om vad som skulle hända dem sedan socialtjänsten bestämt att de skulle placeras. Så här berättar Olle som omhändertogs när han var 7 år om hur han uppfattade socialtjänstens agerande. $\mathrm{O}=$ Olle och $\mathrm{I}=$ Intervjuaren. $(\mathrm{XX})=$ är avkodad information.

\section{Exempel 2 Olle 10 ar}

$\mathrm{O}$ (XX). Jag trodde att. Jag visste liksom inte att vi hade 
blivit omhändertagna och så.

I: Var det ingen som berättade det?

O: Nej.

I: Vad tänkte du då?

O: Jag tänkte att det här bara var ett tag tills mamma kom tillbaka, att mamma var sjuk och på sjukhus eller något, trodde jag.

I: Du visste inte?

O: Nej.

Här framkommer det att Olle inte känt sig informeradom socialtjänstensåtgärder.Han kan därmed ha uppfattat sig som utesluten från möjligheten att delta i planeringen av sina framtida hemförhållanden. Dessutom verkar han inte ha klart för sig hur länge placeringen skulle komma att gälla.

Åtta av de 18 berättelserna handlade om svårigheten att som barn påverka när och hur länge de skulle vara placerade i samhällsvård. Jan var en av dessa åtta och han omhändertogs första gången när han var 4 år. Han berättar nedan om hur han uppfattat sina möjligheter att snart få flytta hem till sin pappa. J= Jan och I= Intervjuaren. $(X X)=$ är avkodad information.

\section{Exempel $3 \mathrm{Jan} 7$ àr}

$\mathrm{J}$ : $(X X)$ jag får bo här, hur mycket jag vill. Jag får bo här ända till att jag blir 14, om jag vill. Fast jag får inte bestämma hur lite jag måste vara här.

I: Får du bestämma?

$\mathrm{J}$ : Nej, jag får inte bestämma hur mycket. Jag får inte bestämma hur lite, jag ska vara här.

I: Vem bestämmer det?

$\mathrm{J}$ : Pelle.

I: Vem är Pelle?

$\mathrm{J}$ : Det är en som är chef.

I: Var är han chef?

J: Jag vet inte vad det heter. Men han jobbar. Han är chef, för att när jag ska hem. Det är han som bestämmer när jag ska hem.
I: Brukar han komma och prata med dig?

$\mathrm{J}$ : Nej, inte så ofta precis.

Jan har förstått att han inte får bestämma när han får komma hem. Han är beroende av ett beslut från Pelle, som bestämmer tidpunkten för hans hemkomst. Pelle är en person med makt, men som inte träffar Jan så ofta för att lyssna på dennes önskemål.

\section{Ej tillfrägad vid val av "vairdare"}

I projektet ingick 17 barn som uppgav att de inte hade blivit tillfrågade när socialtjänsten valde familjehem eller annat typ av boende. Barnen säger att de inte fick ta ställning till om de ville flytta till det av socialtjänsten utsedda boendet innan det redan var bestämt. Lena exempelvis omhändertogs när hon var 12 år. Hon uppger sig inte ha haft något att säga till om vid val av familjehem. L= Lena och I= Intervjuaren.

\section{Exempel 4 Lena 17 år}

I: Men hur fick du reda på det?

L: Jo, det var. Socialen ringde hem. Sedan så satte vi (familjehemsföräldrar och flickan) oss ner, och pratade och så berättade de, att jag skulle flytta till dem.

I: Vem satte sig ner och pratade?

L: Far och mor i huset.

I: Inte socialen?

L: Nej....

Här beskriver Lena sitt möte med familjehemsföräldrarna. Detta möte hade hon uppfattat att det inte var möjligt för henne att påverka eftersom socialsekreteraren redan utsett föräldrarna. Hon är också medveten om att familjehemsföräldrarna informerats

Cederborg, A.-C. \& Karlsson, Y.: Omhändertagande med barnets perspektiv 
om hennes situation innan hon fått lära känna och ta ställning till dem som sina nya "vårdare».

\section{Ingen individuell samtalspartner under placeringstiden}

Det var 13 olika barn och lika många berättelser om att inte få möjlighet att samtala individuellt med socialsekreteraren efter placeringen. Beroende på var barnen var placerade skedde samtalen tillsammans med familjehemsföräldrarna och andra barn i hemmet eller med flera vårdare närvarande. Så här berättar exempelvis Katarina som är 9 år vid intervjutillfället och som varit placerad i familjehem, sedan hon var 5 år. $\mathrm{K}=$ Katarina och $\mathrm{I}=$ Intervjuaren. $(\mathrm{XX})=$ är avkodad information.

\section{Exempel 5 Katarina 9 àr}

$\mathrm{K}$ : (XX). Det var bara jag, familjehemsmam-

man och hennes ena dotter som pratade med socialen.

I: När hon frågade om det var bra här?

Eller vad sade hon?

$\mathrm{K}$ : Ja, hon frågade om det var bra och

det var det.

I: Sade du det då?

$\mathrm{K}: \mathrm{Ja}$.

I: Är det så tycker du?

K: Hm.

I: Trivs du?

K: Hm. Ibland.

Den här beskrivningen kan tjäna som exempel på att Katarina inte fått möjlighet att ensam träffa sin socialsekreterare och med honom eller henne formulera sina tankar och funderingar. När mötet skett har det gjorts tillsammans med personer som hon står i beroendeställning till.

\section{Obehagliga känsloupplevelser}

Det andra huvudtemat utgår ifrån berättelser om när och hur barn känt obehag i förhållande till samhällsplaceringen.

\section{Övergivna vid placeringen $i$ annat boende}

I den här underkategorien inkluderas 12 olika barn som berättar att de känt sig övergivna i samband med placering i annat boende. De har upplevt att placeringen skedde med tvång och/eller att de saknade en inskolningsperiod eller introduktion tillsammans med en bekant vuxen innan de definitivt flyttade in hos sina nya vårdare. Kategorin inkluderar 14 berättelser om övergivenhet.

Tre av de 14 berättelserna handlar om att barn upplevt att de mot sin vilja tvingats till sitt nya boende. Rolfs berättelse får tjäna som beskrivning av detta. Han var 14-år när han skulle placeras. $\mathrm{R}=$ Rolf och $\mathrm{I}=$ Intervjuaren.

\section{Exempel 6 Rolf 15 år}

R: Jag ville inte, jag blev rädd, och sade nej. Så jag var hemma och nu har polisen tagit mig hit. I: Så du åkte ensam ner med poliserna?

R: Ja.

I: Hur kändes det?

R: Det kändes jobbigt och jag blev jätteledsen.

Rolf berättar att han blev rädd och inte ville flytta. Vi vet inte vad som föranlett det här ingripandet från myndigheterna. Men 
faktum är att Rolf har upplevt att transporteringen till annat boende var jobbig, han var rädd och »jätteledsen« när han ofrivilligt skulle föras till annat boende. Polisen tilldelades den auktoritära rollen att med tvång flytta pojken.

Det är 11 av de 14 berättelserna som handlar om att barnen inte fickhjälp av någon bekant vuxen att etablera kontakt med blivande vårdare före placeringen. Julias berättelse är ett exempel på detta. Julia omhändertogs första gången när hon var 6 år. J= Julia och I= Intervjuaren.

\section{Exempel 7 Julia 11 år}

$\mathrm{J}$ : Ja de kom dit och hämtade mig och jag åkte iväg hem till dem.

I: Hade du träffat dem förut?

J: Nej.

I: Hade du aldrig sett dem?

J: Nej.

I: Hur var det?

J: Det kändes konstigt jag visste inte ens vem de var.

Julia visste inte vilka familjehemsföräldrarna var när de kom för att hämta henne. Det vill säga hon var inte bara okunnig om vilka personer som socialtjänsten bedömt skulle kunna ersätta hennes föräldrar. Hon beskriver att hon dessutom försattes i en situation där hon bara hade att följa med för att bo hos helt okända människor.

\section{Inte tagna på allvar}

Barn som misstänks fara illa kan också uppfatta att de inte blir tagna på allvar av socialtjänstens aktörer. Det var 6 barn som gav 14 berättelser om att de på olika sätt upplevt sig underlägsna och hade svårigheter att bli tagna på allvar av sina socialsekreterare. De upplevde sig hotade, kontrollerade, undersökta, utfrågade, inte trodda och skvallrade om.

Tre barn berättar att de inte känt sig trodda när de talat om för sin socialsekreterare att de inte trivs där de är placerade. Här nedan berättar Hanna om detta. $\mathrm{H}=$ Hanna och I= Intervjuaren.

\section{Exempel 8 Hanna 16 år}

I: Lyssnade socialen på dig då?

H: Nej, först i början sade jag: "Ja, det är bra». Men sedan liksom så vände det totalt.

I: Hm. Men när det vände och du berättade det?

H: Då. Nej, liksom: "men det kan inte vara sant", liksom. Men sedan så när de märkte att jag fick skulden, för typ att jag hade gjort dumheter hos dem. Sedan så hade familjehemspappan gått och sagt att jag var fel $i$ huvudet.

Oavsett vad som hade hänt i Hannas familjehem så framkommer att hon först inte uppfattade att socialtjänsten tog henne på allvar.

Två barn beskriver också att professionella skvallrar sinsemellan om dem, de håller inte tyst om det barnen berättar i förtroende till någon av dem. Hans berättar exempelvis hur han uppfattat att hans känsliga berättelse blivit bemött av socialtjänstens aktörer. $\mathrm{H}=$ Hans och $(X X)=$ är avkodad information.

\section{Exempel 9 Hans 15 år}

H: Ja, det är ingen idé att prata. Det så. Om du säger att $(X X)$ du har problem till en. Ja, nästa dag hör du från dem andra: - "Nej, men lilla gubben«. Det går inte att lita på dem.

Samtal mellan personal om vad ungdomar

Cederborg, A.-C. \& Karlsson, Y.: Omhändertagande med barnets perspektiv 
berättat kan, som i Hans fall, resultera i att barnet inte vill vända sig till vårdare. Han beskriver att det inte går att lita på dem, de bryter förtroenden. Detta är problematiskt eftersom personliga relationer mellan ungdomar och personal kan vara en förutsättning för framgångsrika behandlingsmetoder (Levin, 1998).

\section{Saknar sin biologiska familj}

Under vårdtiden upplevde 16 av de 20 barnen att de saknade kontakten med sina biologiska familjer. Bengt berättar att han fortfarande tänker på när han som 11 åring första gången placerades i familjehem och skiljdes från sin mamma. $\mathrm{B}=$ Bengt och $\mathrm{XX}=$ avkodad information.

\section{Exempel 10 Bengt 18 år}

B: Jag tyckte att det var fel. För mamma var den enda trygghet jag hade då, och så slitas ifrån henne. (XX). Då träffade jag mamma varannan vecka. Fick ju åka hem då. Det tyckte jag var lite då. För att det blev inte alls mycket att träffa sin egen mamma, och så bara vissa lov (XX). Ja, det blev så. Vi tappade jättemycket. Men nu, har vi fått jättebra kontakt (XX). Ja, för varje gång då, så sköt de på det ett par månader åt gången. Då är det ganska lång tid, för man skiljs från släktingar och allting. Det blir ju inget helt och sedan varannan vecka. Man tappar kontakten med dem helt enkelt. Det är något jag absolut inte skulle kunna gå igenom en gång till, för det var det jobbigaste.

En nära kontakt med mamma var mycket viktig för Bengt. Under placeringstiden oroade han sig för henne och saknade samvaron med henne och sina släktingar. Han säger att han träffade dem alldeles för sällan, vilket innebar att han tappade kontakten med dem under den tid han var i samhällsvård. Det är problematiskt eftersom placerade barn kan må väl av att behålla kontakten med föräldrar, syskon och andra närstående (Andersson, 1995; Vinnerljung, 1989, Wåhlander, 1995).

\section{Känsla avfrämlingskapi familjehem}

Forskning har visat att barn bör få möjlighet att etablera positiva relationer till sina familjehemsföräldrar för att anpassningen $i$ den nya miljön ska bli så bra som möjligt (Andersson, 1995; 1998a). I den här studien är det 11 olika barn som totalt ger 12 berättelser om känslor av främlingskap i familjehemmet. Åtta berättelser är i förhållande till familjehemsföräldrarna och fyra gäller i förhållande till barnen i familjehemmet. Ulrik som har bott i flera familjehem sedan han var sex år berättar följande. U= Ulrik och I= Intervjuaren. $(X X)=$ är avkodad information.

\section{Exempel 11 Ulrik 12 år}

$\mathrm{U}$ : (XX). Fast de var inte schyssta, de var knäppa tyckte jag.

I: Hur var de då?

U: Nej, men de var jättestrikta regler och så. De var dumma mot en.

I: Vad var det för regler de hade?

U: Man fick ju gå och lägga sig jättetidigt och man fick inte leka med vissa leksaker och sådant. Man fick inte visa känslor.

I: Hur var det?

U: Nej, det var inte alls bra.

Ulrik tyckte inte om familjens uppfostringsmetoder och sätt att förhålla sig till känslouttryck. Han hade svårt att anpassa sig till den nya familjens sätt att fungera. 
Främlingskapskänsla till familjehemssyskon kan illustreras av Saras beskrivning. Hon omhändertogs första gången när hon var 4 år gammal och i följande exempel ger hon uttryck för hur svårt det är för henne när hon blir retad av dottern i den familj där hon bor. $\mathrm{S}=$ Sara och $\mathrm{I}=$ Intervjuaren. $(\mathrm{XX})=$ är avkodad information.

\section{Exempel 12 Sara 7 àr}

S: (XX). När jag blir lika stor som deras dotter.

I: Vad tänker du då?

S: Vad jag ska göra då?

I: Vad då, menar du göra?

S: Om hon retar mig så där när jag är lika stor.

I: Om hon retar dig?

S: Ja, hon kan göra det.

I: Vem ska reta dig menar du?

S: Hon har gjort det några gånger.

I: Jaha. Vad tänker du då? Om hon ska

hålla på med det tills du blir så stor?

S: Ja.

I: Hur känns det?

S: Inget kul.

I: Vad gör hon?

S: Hon säger fula ord till mig ibland.

Sara ger här uttryck för hur svårt det kan vara att hantera att bli retad av dottern i familjehemmet och hur hon tänker på vad hon ska göra åt det när hon blir större.

\section{Ensamhetskänslor}

Av de 20 barnen är det sex som ger sju redogörelser för svåra upplevelser av ensamhet under placeringstiden. Lisa redogör exempelvis för sina tankar om ensamhet under sin tid som samhällsplacerad. $\mathrm{L}=\mathrm{Lisa}$ och I= Intervjuare, (XX) är avkodad identifierbar information.

\section{Exempel 13 Lisa 15 àr}

L: Men jag tyckte, att det var så jobbigt, så jag var mest på mitt rum, och pratade inte så mycket med dem. (XX)

I: Gjorde du det?

L: Hm, så var det jobbigt när deras vänner kom hem och man visste inte var man skulle ta vägen för att man kände sig absolut inte att man hörde till familjen då. Det var ju så. Det var jobbigt och man träffade nya kompisar och så och man skämdes för att man berättade om att man bodde i familjehem och varför.

Det var jobbigt för Lisa att knyta nära kontakter med familjehemmets medlemmar, hon kände sig utanför och ville inte prata med sina kompisar om sin situation. Hon drog sig undan och tillbringade mycket tid $i$ ensamhet under den tid hon vistades i sitt familjehem.

\section{Bestraffad}

Det är framförallt tonåringarna som ger uttryck för att samhällsplaceringarna uppfattats som bestraffningar snarare än stödåtgärder. Det är tre olika barn som berättar om sex fall av isolering, utestängning, permissions- och besöksförbud. Lars berättar följande om sina erfarenheter av bestraffning under vistelsetiden på ett vårdhem. $\mathrm{L}=$ Lars och I= Intervjuaren.

\section{Exempel 14 Lars 15 år}

L: Ja. Då får man hamna där, det finns en annan sida.

I: Har du varit där?

L: Ja, jag har varit där, ja. Jag lyssnade inte, för att jag gillar inte att någon ska bestämma. Om du glömmer. Om du inte har tofflor nu, och du säger - "Nej, jag vill inte ha tofflor». Du kanske har ont i huvudet eller du kanske har problem.

Cederborg, A.-C. \& Karlsson, Y.: Omhändertagande med barnets perspektiv 
Då säger de - "Neju. Sedan bråkar du och skriker: - "Jag vill inter. Då kastar de dig. De tar dig två eller tre stycken så, så hamnar du där. Sedan får du inte göra nästa gång någonting. Du går runt här hela tiden. Det är sådana regler som de har säger de.

I: Hur länge får du sitta där?

L: En hel dag.

Lars har erfarit att motsträvighet bestraffas med isolering. Det är personalen som har makt att avgöra när han begår felsteg och då är det fysisk förflyttning till ensamhet som ska få honom att tänka över sitt agerande.

Enannan uppfattad vårdideologibeskrivs av Klas när han berättar om hur han blev utestängd från sitt boende för att han kommit hem för sent en kväll. K=Klas.

\section{Exempel 15 Klas 18 år}

K: Ja, när jag kom för sent. Då kunde de låsa alla dörrarna, så jag inte kunde komma in. Så efter ett tag, så kom de och öppnade då.

\section{Positiva erfarenheter av samhällsåtgärder}

I analysarbetet framträdde inte teman om positiva erfarenheter av socialtjänstens ageranden i någon större utsträckning. Det var två tonåringar som explicit uttryckte att de blivit hjälpta genom socialtjänstens agerande. Per som omhändertogs första gången när han var 12 år berättar exempelvis hur han efteråt kan se att han hade nytta av sin placering. $\mathrm{P}=$ Per och $\mathrm{I}=$ Intervjuaren. $(\mathrm{XX})=$ är avkodad information.

\section{Exempel 16 Per 16 år}

P: (XX). Men om man tänker nu, så var det väl bra att jag kom ifrån det.

I. Det var det?

P: Ja, verkligen. De har hjälpt mig med att försöka få föräldrarna att säga nej, om jag säger. Försöka få mig att förstå att det inte bara är att göra allting. Inte bara komma och gå som man vill. Det är väl den hjälpen.

Per anser att både han och föräldrarna har fått hjälp att förändra sitt agerande genom socialtjänstens försorg. Han säger sig nu kunna förstå vad som tidigare kunde ha varit orsaken till hans problem.

\section{Diskussion}

Syftemed dennastudievar att lyfta fram hur 20 barn i en medelstor svensk kommun har uppfattat socialtjänstens agerande i samband med insatser som syftade till att förbättra deras livssituation. Det finns anledning att diskutera tillförlitligheten i det barnen har berättat även om begreppen validitet och reliabilitet inte är tillämpliga i en kvalitativ studie med barnintervju som forskningsmetod (Andersson, 1998b). Barnen kan ha påverkats av både intervjuaren och intervjusituationen. Dessutom kan de ha valt att avstå från att berätta om känsliga detaljer. Det barnen redogör för behöver därför inte vara lika med vad som faktiskt hänt. Berättelserna är därmed inte objektiva fakta utan snarare det enskilda barnets subjektiva upplevelser och erfarenheter framtagna i samspel med en för dem okänd person.

Barnets motivation att berätta kan ha varierat och naturligtvis påverkat de svar som getts. Deras berättelser ska också förstås i ljuset av vad de minns av olika hän- 
delseförlopp och att de berättar i »backspegelns" ljus. Det innebär att de efterkonstruerar sina uppfattningar utifrån vad de minns och de kan också välja vad de vill avslöja och vilken bild de vill förmedla. Anledningen till att barnens svar ser ut som det gör kan alltså variera. $\AA$ andra sidan har endast en intervjuperson träffat barnen och dessutom avstått från att pressa barnet på detaljåtergivning. Frågorna har handlat om faktiska förhållanden som barnen upplevt och de har gett svar på de frågor som studien ämnade att belysa. Deras beskrivningar har inte ifrågasatts utan i stället förståtts som den verklighet barnen velat förmedla till intervjuaren.

Det var också 20 barn som av olika själv inte kunde delta i studien. Avsikten är inte att hitta generaliserbara fakta utan resultaten ska förstås utifrån det unika barnets återgivning av sina erfarenheter. Därmed ska svaren kunna ge en bild av hur det individuella barnet tänker kring socialtjänstens bemötande.

Utgångspunkten för intervjuerna var att respektera barnets återgivning av sin verklighet. Mot den bakgrunden framstår att de flesta har förstått att de levt i situationer som enligt svensk sociallagstiftning kan definieras som riskmiljöer. De berättar exempelvis om barnmisshandel, om föräldrar som missbrukar eller är psykiskt sjuka och inte orkat med dem. De återger också svårartadekänslor isamband med föräldrars skilsmässa eller när släktingar dött. Några barn berättar om egna bekymmer som de har i skolan, kring eget missbruk och kriminalitet. Berättelserna legitimerar socialtjänstens utredningsarbete, men problemet är att barnen uppfattat sin deltagarstatus som låg både under tiden för utredningen och efteråt. De säger sig inte bli eller blivit lyssnade på i någon större utsträckning och därmed har inte deras perspektiv tillvaratagits av de personer som har att bevaka deras intressen.

Mer konkret handlar det om att cirka tre fjärdedelar av de 20 barnen säger sig inte ha blivit samtalade med under utredningsarbetet. Nästan samtliga säger att de inte fått information om socialtjänstens planerade åtgärder. De beskriver exempelvis att de inte fått veta att det fanns beslut om LVU- åtgärd och att de skulle tvångsplaceras i familjehem, de känner sig osäkra på hur länge de ska vara placerade och de saknar samtalskontakt med ansvarig socialsekreterare som kan ge information om vad som kommer att hända dem framöver. En del säger också att de inte fått möjlighet att samtala med socialarbetaren enskilt under boendeplaceringen. I stället får de prata med socialsekreteraren när andra personer är närvarande. Då vill de inte alltid framföra sina åsikter, för att inte såra någon men också för att de inte vill avslöja sina innersta tankar av rädsla för efterföljande konsekvenser.

Detta är beskrivningar som stärker intrycket av att samhällsinsatser som syftar till att bevaka barns intressen sker "över huvudet« på dem. De blir åskådare snarare än medaktörer och de uppfattar inte att de har vare sig möjlighet eller rättighet att påverka socialtjänstens ageranden. Detta är problematiskt, eftersom socialtjänstens åtgärder i allra högsta grad förändrar och påverkar deras livssituation.

Barnen beskriver också att de haft obehagliga känsloupplevelser under den tid som

Cederborg, A.-C. \& Karlsson, Y.: Omhändertagande med barnets perspektiv 
socialtjänsten utrett och varit ansvarig för deras boende. Mer än hälften av barnen har känt sig övergivna i samband med placeringen $i$ annat boende. Många säger att de inte blir tagna på allvar av framförallt socialsekreterare men också av vårdande personal. Likaså har de flesta upplevt att de saknat sina nära anhöriga och tycker att de har för lite kontakt med dem under placeringstiden. Flera av dem är också oroliga för vad som händer i deras biologiska familj när de inte finns där. De har också egna problem som de inte känner att de har någon att prata med om. Några barn berättar att de är osäkra på hur de ska hantera sin situation i familjehemmet t.ex hur de ska whitta sin plats« i den nya familjen.

Några ungdomarär besviknaöver attsamhällsvården innehåller bestraffningar snarare än samtal med vårdare. De säger att de inte alltid vågar lita på att personalen inte sviker deras förtroenden.

Svenska forskare har belyst omhändertagna barns möjligheter till anpassning $i$ familjehem (exempelvis Andersson, 1991; 1995; 1998a) eller till $\S 12$ hem (Levin, 1998). Där framkommer bland annat att barn bör bibehålla kontakten med sina föräldrar och andra för dem viktiga relationer och etablera positiva relationer till sina familjehemsföräldrar för att anpassningen $\mathrm{i}$ den nya miljön ska bli så bra som möjligt. Det barnen återger i den här studien kan tyda på att de haft svårigheter att anpassa sig till de nya miljöer socialtjänsten erbjudit. Bristande kontakt med biologiska hemmet och avsaknaden av inskolningsperiod skulle i så fall kunna vara en förklaring till detta.

Denna studie visar precis som andra att socialsekreterare tycks undervärdera sin betydelse som utsatta barns stöd och samtalspartners (Andersson, 1995). Genom att inte samtala med barnet kan socialsekreterare missa möjligheten att få reda på dess individuella livserfarenhet och egna tankar. Intervjuer med barn är ett av de viktigaste verktygen för att få en förståelse för barnets situation och perspektiv men kan också vara en av de största utmaningarna en socialarbetare kan stå inför. Det gäller nämligen att inte bara tala med barnet utan verkligen lyssna på vad det har att säga. Det handlar om genuina dialoger, där barnet lyssnas till på ett öppet och förutsättningslöst sätt. Det är barnets beskrivning som ska komma fram och den ska inte färgas av vad socialarbetare vill höra (Aronsson, 1996; 1997).

Tidigare forskning av placerade barn har visat att barn har förmåga att berätta om sig själva och sin situation (Andersson, 1998b). När barn betraktas som aktiva subjekt, med egna erfarenheter att förmedla, blir det möjligt att ta till vara vad de har att berätta (Andersson et al, 1996). Den här studien tyder också på att barn både vill och kan ge en bild av sina upplevelser. Tyvärr bekräftar deras återgivning bilden av barnet som objekt snarare än subjekt i socialtjänstens arbete, vilket inte är i överensstämmelse med ambitionerna inom svensk sociallagstiftning.

Vad beror det på att barnperspektivet kan vara så begränsat inom socialtjänsten? Svaret är säkerligen komplext, men en förklaring förutom bristande kunskaper om barn, är att barn och framförallt de som kan tänkas vara utsatta i någon bemärkelse har låg status i vårt samhälle. Därmed kan det falla sig naturligt att inte tro på deras betydelse och kompetens att berätta och därmed 
försvåras det för socialtjänsten att radikalt förstärka betydelsen av utsatta barns "röst" $i$ arbetet med dem.

En annan förklaring är att det inom socialtjänsten kan finnas en rädsla för att barn kan säga att de inte vill flytta från sina föräldrar. Sådan information kan vara svår att hantera.

En tredje förklaring kan vara att socialsekreterare anser att barn inte ska behöva berätta för att undgå risken att hamna i en lojalitetskonflikt mellan sina föräldrar och socialtjänsten.

Ett fjärde skäl skulle kunna vara att socialsekreterare känner sig osäkra på hur de ska hantera den information de skulle kunna få från barnet, den information som skulle kunna tjäna som beslutsunderlag när socialnämnden och länsrätten ska bedöma vilken åtgärd som är den bästa för just det barnet. Oavsett orsaken bidrar ett undvikande att intervjua barnet till att socialarbetaren inte får fram tillräckligt "bevisunderlag" för ett eventuellt omhändertagandebeslut och barnet riskerar att inte känna sig hjälpt av socialtjänstens insatser (Cederborg, 2000). Kravet påatt lyfta fram barnets egen beskrivning bör därför bli tydligare i socialvårdens arbete. Annars är det svårt att avgöra om det är vuxna som tolkat barnets behov eller om det är barnets egna utsagor som beskrivningarna utgår ifrån (Hollander, 1998). Får inte barn tillfälle att berätta finns det risk för att deras rättigheter inte tas till vara på ett tillfredställande sätt. Informationen som barnet ger måste ju naturligtvis hanteras på ett sådant sätt att barnet skyddas. Det viktiga är att barnet inte uppfattar ett förstärkt utanförskap i en så genomgripande åtgärdsprocess som ett omhändertaganden enligt LVU medför.

\section{Litteratur}

Andenaes, A. (1991). Fra undersökelseobjekt til medforsker? Livsformsintervju med 4-5 åringer. Nordisk Psykologi, 43 (4), 274-292.

Andersson, (1991). Socialt arbete med små barn. Lund: Studentlitteratur.

Andersson, G. (1995). Barn i samhällsvård. Lund: Studentlitteratur.

Andersson, G.(1998a). „Föräldrakontakt och familjetillhörighet ur fosterbarns perspektiv« Socialvetenskaplig tidskrift, 5, 3-23.

Andersson, G. (1998b). Barnintervju som forskningsmetod. Nordisk psykologi, 50 (1), 18-41.

Andersson, G. (1999). „Children in residential and fostercare - a Swedish exampleu. International Journal of Social Welfare, 8: 253-266.
Andersson, G., Aronsson, K., Hessle, S., Hollander, A., \& Lundström, T. (1996). Barnet i den sociala barnavairden. Stockholm: Centrum för utvärdering av socialt arbete/ Liber.

Aronsson, K. (1996). „Barnintervju och barnets röstu. IG. Andersson, K. Aronsson, S. Hessle, A. Hollander, \& T. Lundström. Barnet $i$ den sociala barnavården. Stockholm: Centrum för utvärdering av socialt arbete/ Liber.

Aronsson, K. (1997). »Att tala med barn«. I Socialvetenskapligtidskrift, Med fokus på barn. Stockholm: Socialvetenskapliga forskningsrådet.

Barnet i rättsprocessen. SOS- rapport (1995:21)

Barnkommittén SOU (1997: 116). Barnets bästa $i$ främsta rummet. FN:s konvention om barnets

Cederborg, A.-C. \& Karlsson, Y.: Omhändertagande med barnets perspektiv 
rättigheter i främsta rummet. Stockholm: Socialdepartementet.

Butler,I.,\& Williamsson,H. (1994). Children speak. Children, trauma and social work. Essex: Longman Information and Reference.

Börjeson, B., \& Håkansson, B. (1990). Hotade, försummade, övergivna- är familjehems placering en möjlighet för barnen? Stockholm: Rabén \& Sjögren.

Cederborg, A.-C. (2000). Barnintervjuer. Vägledning för utredningsarbete. Stockholm: Liber.

Claezon, I. (1987). Bättre beslut. Umeå: Umeå Universitet.

Cleaver,H.,Unell,I.,\&Aldgate,J.(1999). Children's needs - Parenting capacity. London: The Stationery Office.

Farmer, E., \& Owen, M. (1995). Child protection practice: Private risks and public remedies. London: HMSO publication center.

Hagbard, S., \& Esping, U. (1992). Med barns ögon. Om ett barnrelaterat förhållningsätt i familjehemsvården. Stockholm: Allmänna Barnhuset.

Hessle, S. (1998). Child welfare and child protection. Edsbruk: Akademitryck AB.

Hollander, A. (1985). Omhändertagande av barn. Stockholm: Aktuell juridiskt förlag.

Hollander, A. (1998). „Barnens rätt att komma till tals - ökat inflytande för barn eller vuxna?» Nordisk Sosialt Arbeid, 4 (18), s. 194-200.

Holstein, J. A., \& Gubrium, J. F. (1995). The active interview. CA: Sage.

Hyden, L-C. (1997). »De otaliga berättelserna». I L-C Hyden \& M. Hyden (red). Att studera berät telser. Stockholm: Liber.

James, A., \& Prout, A. (1990). Constructing and reconstructing childhood: Contemporary issues in the sociological study of childhood. London: The Farmer Press.

Kommittédirektiv för översyn av Lag om vård av unga. (1999: 43).

Konventionen om barnets rättigheter. (1990). Stockholm: Utrikesdepartementet, UD informerar 1990: 6

Kvale, S. (1997). Den kvalitativa forskningsinterviun. Lund: Studentlitteratur.

Lamb, M. E. (1994). „The investigation of child sexual abuse: An interdisciplinary consensus statement." Child Abuse \& Neglect, 18, 1021-1028.

Levin, C. (1998). Uppfostringsanstalten. Om tvaing i föräldrars ställe. Lund: Lunds Universitet.

Mattson, Titta. (1998). „Barnets mening i LVU processen". Socialvetenskaplig tidsskrift. 1.

Pringle K., \& Harder, M. (1999). Through two pairs of eyes: A comparative study of Danish social policy and child welfare. Aalborg: Aalborg university press.

Rasmusson, B. (1994). Barnperspektiv. Stockholm: Barnombudsmannen.

Reder, P., \& Duncan, S. (1999). Lost innocents. London: Routledge.

Reznik, J. S., \& Kagan, J. (1982). „Category detection in infancy". I L. P. Lipsett och C. K RoveeCollier (red.). Advances in infancy research. Vol 2 Norwood, NJ: Ablex sid 80-111.

Reissman. C.K.(1993). Narrativeanalysis. London: Sage.

Quinton, D., Rushton, A., Dance, C., \& Mayers, D. (1998). Joining new families. A study of adoption and fostering in middle childhood. West Sussex England: John Wiley \& Sons Ltd.

Qvartorp, J., Bardy, M., Sgritta, G., \& Wintersberg, H. (1994). Childhood matters. Social theory, practice and politics. Wien: Aldershot, Avebury Euorpeen Center.

Socialstyrelsens rapport (2000:1). Sexuella övergrepp mot barn. En kunskapsöversikt. Stockholm: Modin Tryck.

SOU(2000:77). Omhändertagen. Samhälletsansvar för utsatt barn och unga. Stockholm: Nordstedts Tryckeri.

Socialtjänstlagen (1980: 620).

Tiller, P-O. (1991). „Barneperspektivet» - om å se och bli sett. I: Barn - nytt fra forskning om barn $i$ Norden 1. Trondheim: Senter för barneforskning. Vinnerljung,B.(1989). Fosterhemsförvaltning.Lund: Socialhögskolan.

Vinnerljung, B. (1996). Fosterbarn som vuxna. Lund: Arkiv förlag.

Wåhlander, E. (1995). Att allsidigt belysa barns sociala situation. Stockholm: Stockholms Universitet. 


\section{Summary \\ Placement from the children's perspective}

The United Nations Child Convention has had radical influences on the Swedish legislation relating to how to handle the perspective of the child when the social welfare department suspects that children are at risk. This means that in every case where there is a suspicion of a child being mistreated, the good of the child is the guiding star for the investigation and suggested actions in the matter. The legislation requires that social workers interview these children and let them give their opinion of their life situation, as well as regulating what has to be taken care of by the social welfare in order to make life easier for them. This study illuminates how children have understood their own status during the social investigation of their life situation. Twenty children (5-19 years of age) that have been taken care of by the social welfare were interviewed about their experiences. The conclusions are that children are in an asymmetrical position during the social investigation of their case. Most of the children did not recall that they had any opportunity to give their perspective during the investigation. They also expressed unpleasant experiences such as abandonment, and several felt that they were not taken seriously. Most of them said they miss the contact with their biological parents during the foster-care placement.

Cederborg, A.-C. \& Karlsson, Y.: Omhändertagande med barnets perspektiv 